\title{
New, simple method of examining toddlers' abilities to use absent objects
}

\author{
Kiyobumi Kawakami (Department of Psychology, University of the Sacred Heart, kawakami@u-sacred-heart.ac.jp) \\ Kiyoko Takai-Kawakami (Japan Women's University, takaikawakami@gmail.com) \\ Fumito Kawakami (Department of Psychology, Chubu University, kawakami@fsc.chubu.ac.jp)
}

\author{
幼児の目に見えない物を使う能力を調べる新しく、簡便な方法 \\ 川上清文（聖心女子大学心理学科） \\ 高井 清子（日本女子大学） \\ 川上文人（中部大学心理学科）
}

要約

私たちは、「幼児の見えない物を使う能力を調べるための方法」を考案し、実験してみた。この方法では複雑な手続きや 言語教示を必要としない。研究 1 では 10 人の幼児を対象とし、実験手続きと、「拒否・無視」から「言語反応」までの 発達の 5 過程が確立された。研究 2 では 67 人が対象となり、発達の 5 過程は対象児の日齢と相関寸ることが示された。 そして研究 3 では 11 人の対象児を縦断的に追跡したところ、過程は安定していたことが明らかになった。本論文で示さ れた新しい方法は、今後幼児の認知発達を研究するのに有効であろうと考えられる。

\section{Key words}

toddlers, absent objects, new and simple method, developmental process, cognitive development

\section{Introduction}

"The ability to refer to and convey information about absent objects and events is an essential feature of human language.... Developing the ability to understand references to absent objects and events is thus a major cognitive achievement, one that enables children to communicate about what is not perceptually present (Ganea, 2005, p. 989)." Ganea (2005) described that children begin to use words to refer to absent objects and people at about 18 months of age, but they may understand references to absent objects earlier than this age. In one experiment (Ganea, 2005) 13- and 14-month old children first played with a named stuffed animal for seven minutes and infants heard the name of the toy about 86 times. In the test phases, infants displayed behaviors that indicated remembering the name of the invisible toy. Saylor and Ganea (2007), and Osina, Saylor and Ganea (2013) adapted nearly the same experimental paradigm and used verbal questions such as "Where is the ball?" in the condition when the ball was invisible.

In the case of chimpanzees, experimenters cannot use verbal instructions or get verbal responses (Liszkowski, Schafer, Carpenter, \& Tomasello, 2009). Liszkowski et al. (2009) claimed that both human infants and chimpanzees could use nonverbal pointing gestures for referring to things, although human infants could also point when referring to absent entities, which is not the case with chimpanzees. Lyn, Russell, Leavens, Bard, Boysen, Schaeffer, and Hopkins (2013) showed that chimpanzees and bonobos could communicate about absent objects. They accounted for these conflicting findings by referring to other stud- ies and minor methodological differences between studies, such as "true absent" as opposed to "visibly displaced, but still present". Bohn, Call, and Tomasello (2015) demonstrated that bonobos, chimpanzees, gorillas, and orangutans could communicate about absent entities. These results suggest that such cognitive abilities are independent of language.

Kawakami (2014) presented data showing that toddlers could pretend to give an adult observer an absent thing (air?), but not give a physical object. Kawakami and Takai-Kawakami (2015) also observed a toddler pretending to get something from a peer when there was no physical object. Moreover, Kawakami and Takai-Kawakami (2017) showed that toddlers could give nursery teachers something that was not a physical object. These results show that toddlers could use absent objects in their daily lives.

We report three studies that used a new, simple method to examine toddlers' abilities to use absent objects. The method used in these studies did not require complex verbal instructions, a complex setup, or complex responses. Therefore, it was expected that methodological problems caused by these variables would not be encountered when using the new method due to its simple procedure.

\section{Study 1: Developing the experimental method 2.1 Method \\ 2.1.1 Purpose}

We attempted to develop a new method for investigating children's understanding of absent objects using procedures, which did not depend on verbal instructions.

\subsubsection{Participants}

Toddlers $(N=10,5$ girls and 5 boys, $M=590.50$ days, $S D$ $=245.54$ ) were recruited from authors' relations. At the time of the experiment, they were typically developed and were being 
cared for by their mothers in their homes.

\subsubsection{Procedure}

The participants and the two experimenters (one experimenter was the first author, and the other, the second author) met for the first time. Participants were brought by their parent(s) to the laboratory, a park, or a shopping mall. The purpose and procedures of the study were explained to the parent(s), and their written informed consent was obtained for the participation of their children. After making rapport, the experimenter presented the palms of his hands in front of the toddler saying "Douzo" (Meaning "Please, take one" in Japanese. See Figure 1-5). All the procedures of the experiment were recorded using a video camera (Sony, HDR-CX180) by the second author. The ethics committee of the University of the Sacred Heart reviewed and approved the conduct of this study.

\subsubsection{Coding}

We tentatively determined the potential coding "Processes of toddlers' responses" through our prior experiences in nurseries and estimated their stage of cognitive development as ranking from Process 1 to Process 5 with Process 5 indicating the highest stage of development. Process 1 consisted of "Rejecting or ignoring (Figure 1)", Process 2 consisted of Giving an object(s) to the experimenter (Figure 2)", Process 3 consisted of Putting own hand(s) on the experimenters' palms (Figure 3)", Process 4 consisted of "Imaging the absent objects(s) with their own hands (Figure 4)", and Process 5 consisted of "Verbal responses

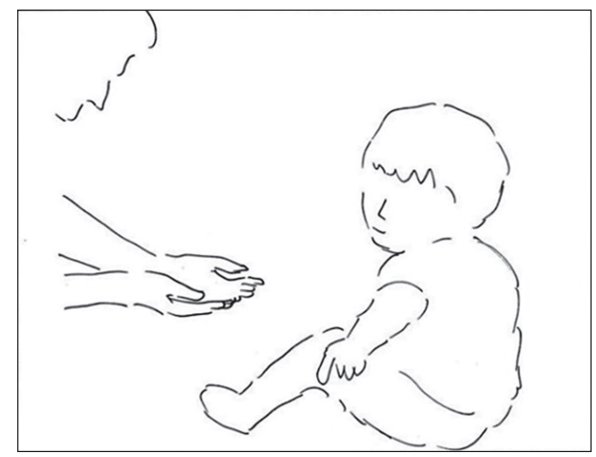

Figure 1: Process 1

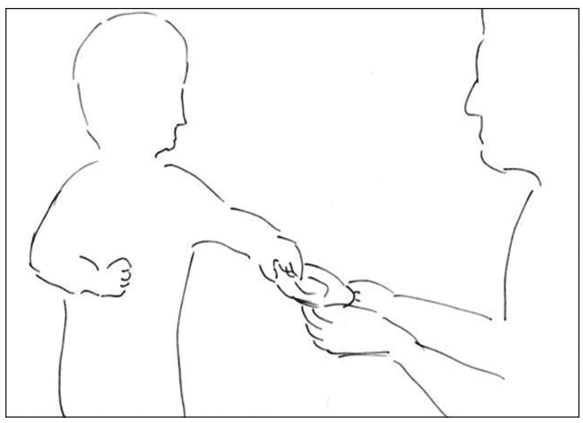

Figure 2: Process 2

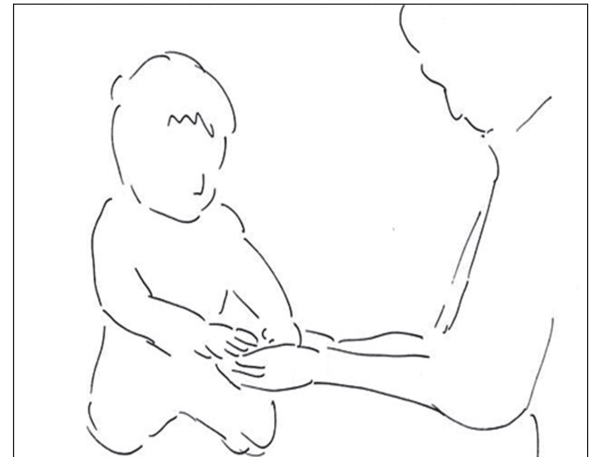

Figure 3: Process 3

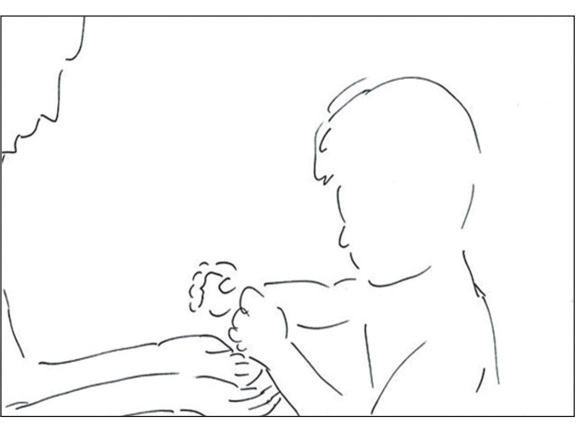

Figure 4: Process 4

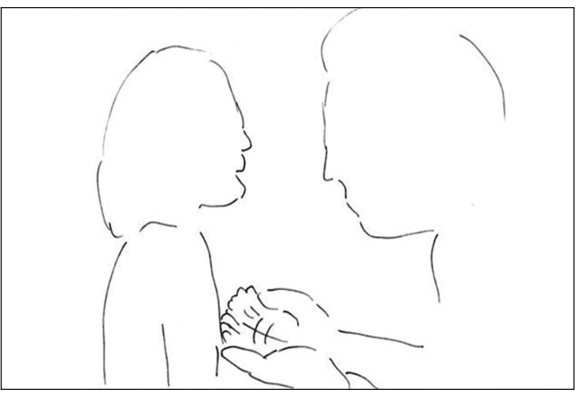

Figure 5: Process 5

(Figure 5)". If a child's response consisted of two Processes, the final Process was defined by the higher Process. Intercoder reliabilities for data of Study 2 are presented below.

\subsection{Results}

Table 1 shows the results. We inquired from the parents about the linguistic development of their children by using the following categories (one-word user, two-word user, or threeword user). Two children in Process 4 did not respond about what they imaged. The verbal responses of these two children in the five Processes were "Nothing".

\subsection{Discussion}

It is clear from Table 1 that toddlers' coding Processes and language level might develop gradually. Girls were older than boys among the participants in Study 1. Therefore, we cannot make any conclusions on gender differences from Study 1 and 
Table 1: Results of Study 1

\begin{tabular}{ccccc}
\hline No. & Day in age & Gender & Process & Words \\
\hline 1 & 280 & $\mathrm{M}$ & 1 & 1 \\
2 & 365 & $\mathrm{M}$ & 3,1 & 1 \\
3 & 386 & $\mathrm{M}$ & 3,2 & 1 \\
4 & 387 & $\mathrm{M}$ & 3 & 1 \\
5 & 559 & $\mathrm{~F}$ & 2 & 1 \\
6 & 648 & $\mathrm{M}$ & 5 & 2 \\
7 & 710 & $\mathrm{~F}$ & 1 & 1 \\
8 & 722 & $\mathrm{~F}$ & 4 & 2 \\
9 & 760 & $\mathrm{~F}$ & 4 & 2 \\
10 & 1,088 & $\mathrm{~F}$ & 5 & 3 \\
\hline
\end{tabular}

gender differences are planned to be examined in Study 2.

The results of Process 2 indicated that presenting the palms of both hands in front of them had the meaning, "Give me something" for certain children. The results of Study 1 suggested that the method of our study reflected the cognitive development of toddlers and that the coding into the five Processes was an appropriate scale for understanding toddlers thinking about absent entities.

\section{Study 2: Large-scale sampling}

\subsection{Method}

\subsubsection{Purpose}

We performed the identical experiments as in Study 1 with a large number of participants to validate the research method.

\subsubsection{Participants}

Children $(N=67$; Age range 263-1079 days, 31 girls, $M=$ $659.55, S D=214.84$, and 36 boys, $M=622.33, S D=197.27)$ from two nursery schools in Tokyo, Japan participated in the study. There were no gender differences in the age of the participants $(F(1,65)=.55, p<.46)$.

\subsubsection{Procedure}

The identical procedure as in Study 1 was conducted in nursery schools. The children played freely with peers and teachers in school rooms or the grounds. The experimenter (the first author) played with a child for some time and presented the palms of his hands in front of the child saying, "Douzo". The complete procedure was recorded using a video camera (Sony, HDR-CX180) by the second author. The written informed permission was obtained from school teachers before conducting this study. The ethics committee of the University of the Sacred Heart reviewed and approved the study.

\subsubsection{Coding}

The data coding in different Processes was performed by the first author. Half of the data, 34, were independently coded by the third author. The intercoder agreement reached $100 \%$ be- cause of the simplicity of the coding method.

\subsection{Results}

Table 2 shows the results of Study 2. Results indicated no gender differences based on the Process (girls $=1.94$, boys $=$ $2.39, F(1,65)=2.26, p<.14)$. To address whether older children made classifications in higher Processes than younger children, the age in days was compared with the Process numbers for each child. Spearman's rank correlation indicated significant $(r(67)=.36, p<.01)$. Some older children made Process 1 classifications (Rejecting or ignoring) and also showed complex responses other than rejecting or ignoring, such as thinking. Two children made Process 4 classifications by grasping something and pretending to eat it. One child made a Process 5 classification by grasping something and saying "Riceball". Moreover, one child made a Process 5 classification and said "Nothing". A set of identical twin girls were included in the participants. Of these, one girl was classified into Process 4 and the other into Process 1 .

Table 2: Results of Study 2

\begin{tabular}{crrrrr}
\hline Process & 1 & 2 & 3 & 4 & 5 \\
\hline Female & 19 & 2 & 4 & 5 & 1 \\
Male & 12 & 4 & 15 & 4 & 1 \\
\hline
\end{tabular}

\subsection{Discussion}

The five Processes of coding were considered an appropriate scale to categorize children's understanding of absent entities. In Process 1, the meanings of responses might have been varied. Certain children classified into Processes 4 and 5 imaged food as the absent object. There were no gender differences in the participant's Processes. However, the data on the only set of identical twins did not result in any significant findings.

\section{Study 3: Longitudinal data}

\subsection{Method}

\subsubsection{Purpose}

The eleven children ( 5 girls and six boys) in Study 2 were observed twice in Study 3, which was conducted after Study 2 to check the stability of the Processes.

\subsubsection{Participants}

Eleven children performed the experiment three times. Their mean age during Study 2 (the first experiments) was 411.55 days $(S D=76.86)$, whereas it was 523.91 days $(S D=79.52)$ during the second experiment and 654.64 days $(S D=76.13)$ during the third experiment.

\subsection{Results}

Table 3 shows the results of the three groups for each child: stable, up, and mixed. 
Table 3: Results of Study 3

\begin{tabular}{ccc}
\hline Stable & UP & Mixed \\
\hline $1 \rightarrow 1 \rightarrow 1$ & $1 \rightarrow 1 \rightarrow 4$ & $1 \rightarrow 3 \rightarrow 1$ \\
$1 \rightarrow 1 \rightarrow 1$ & $1 \rightarrow 3 \rightarrow 3$ & $3 \rightarrow 3 \rightarrow 1$ \\
$1 \rightarrow 1 \rightarrow 1$ & $2 \rightarrow 3 \rightarrow 3$ & \\
$1 \rightarrow 1 \rightarrow 1$ & & \\
$4 \rightarrow 4 \rightarrow 4$ & & \\
$4 \rightarrow 4 \rightarrow 4$ & & \\
\hline
\end{tabular}

For example, the child $(1 \rightarrow 1 \rightarrow 1)$ shows that she or he was classified in Process 1 in all three experiments. These results show that six children maintained a stable developmental Process, whereas three children moved up to a higher developmental Process. Moreover, one child $(3 \rightarrow 3 \rightarrow 1)$ in the mixed group responded with laughter and ignoring during the third experiment.

\subsection{Discussion}

The results of Study 3 indicated that the Processes of children's development were nearly consistent. It was considered that children might have moved to a higher Process because of cognitive development during the three experiments. The results of one child in the "mixed group" $(3 \rightarrow 3 \rightarrow 1)$ also indicated cognitive development.

\section{General discussion}

Only a small number of children were classified into Process 2 and 5 in Studies 1 to 3. Therefore, Processes 2, 3 and 4, 5 were collapsed into single Processes A, B, and C. Process A was defined as "Rejecting or ignoring," which was identical to Process 1 and Process B was defined as "Giving something to the experimenter, or Putting own hand(s) on the experimenters' palms", and Process $\mathrm{C}$ was defined as "Imaging something with their own hand(s), or Verbal responses". Figure 6 shows the combined results of the three studies and facilitates understanding absent entities that are imagined by toddlers.

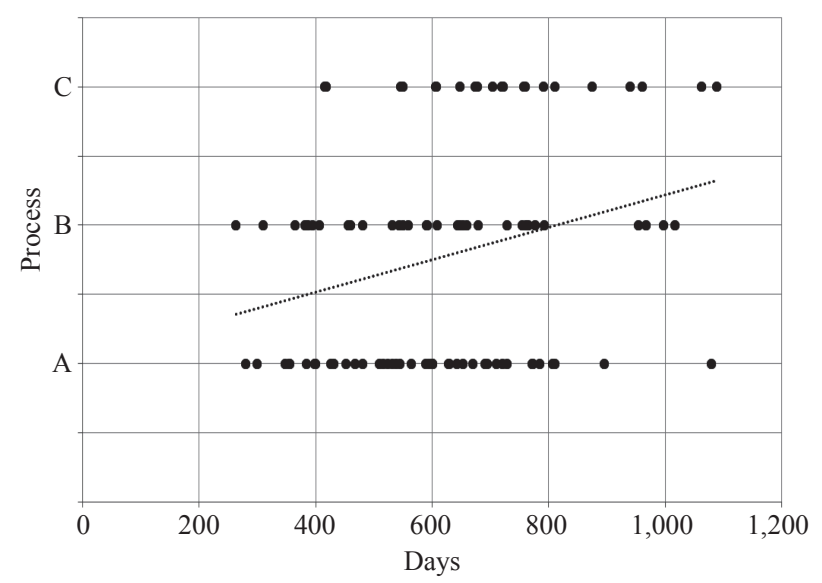

Figure 6: Development of toddlers' abilities to use absent objects
Understanding absent entities might be related to children's pretend play. Lillard, Lerner, Hopkins, Dore, Smith and Palmquist (2013) in a review of a large number of studies claimed that "existing evidence does not support strong causal claims about the unique importance of pretend play for development and that more and better research was essential for clarifying its possible role". It is hoped that our studies that developed a new, simple method of conducting these studies would shed light on pretend play.

\section{Acknowledgements}

The authors would like to thank toddlers, parents, and nursery teachers. And we wish to express our appreciations to Keiko Teramura, Keiko Watanabe, and Jun Nakamura.

The authors have no conflicts of interest directly relevant to the content of this article.

\section{References}

Bohn, M., Call, J., \& Tomasello, M. (2015). Communication about absent entities in great apes and human infants. Cognition, 145, 63-72.

Ganea, P. A. (2005). Contextual factors affect absent reference comprehension in 14-month-olds. Child Development, 76, 989-998.

Kawakami, K. (2014). The early sociability of toddlers: The origins of teaching. Infant Behavior \& Development, 37, 174177.

Kawakami, K. \& Takai-Kawakami, K. (2015). Teaching, caring, and altruistic behaviors in toddlers. Infant Behavior \& Development, 41, 108-112.

Kawakami, K. \& Takai-Kawakami, K. (2017). Toddlers perceive preschool teachers not only as caregivers but also as life partners. Journal of Human Environmental Studies, 15, 31-34.

Lillard, A. S., Lerner, M. D., Hopkins, E. J., Dore, R. A., Smith, E. D., \& Palmquist, C. M. (2012). The impact of pretend play on children's development: A review of the evidence. Psychological Bulletin, 139, 1-34.

Liszkowski, U., Schäfer, M., Carpenter, M., \& Tomasello, M. (2009). Prelinguistic infants, but not chimpanzees, communicate about absent entities. Psychological Science, 20, 654-660.

Lyn, H., Russell, J. L., Leavens, D. A., Bard, K. A., Boysen, S. T., Schaeffer, J. A., \& Hopkins, W. D. (2014). Apes communicate about absent and displaced objects: Methodology matters. Animal Cognition, 17, 85-94.

Osina, M. A., Saylor, M. M., \& Ganea, P. A. (2013). When familiar is not better: 12-months-olds infants respond to talk about absent objects. Developmental Psychology, 49, 138-145.

Saylor, M. M. \& Ganea, P. (2007). Infants interpret ambiguous requests for absent objects. Developmental Psychology, 43, 696-704.

(Received August 31, 2018; accepted October 31, 2018) 